\title{
SEDIMENTARY ZEOLITE DEPOSITS OF THE UPPER MATANUSKA VALLEY, ALASKA
}

\author{
By D. B. Hawkins \\ Geology Department \\ UnIVERSITY OF Alaska
}

SPECIAL REPORT 6

Prepared by D. B. Hawkins in cooperation

with the Alaska Division of Geological \& Geophysical Surveys

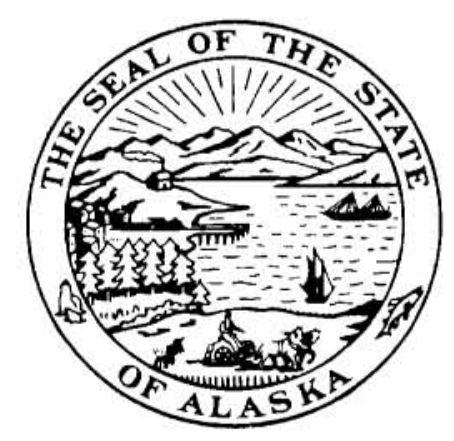

Published by

DIVISION OF GEOLOGICAL \& GEOPHYSICAL SURVEYS

COLLEGE, ALASKA
1973 
STATE OF ALASKA

William A. Egan, Governor

\section{DEPARTMENT OF NATURAL RESOURCES}

Charles F. Herbert, Commissioner

DIVISION OF GEOLOGICAL \& GEOPHYSICAL SURVEYS

Donald C. Hartman, State Geologist 


\section{CONTENTS}

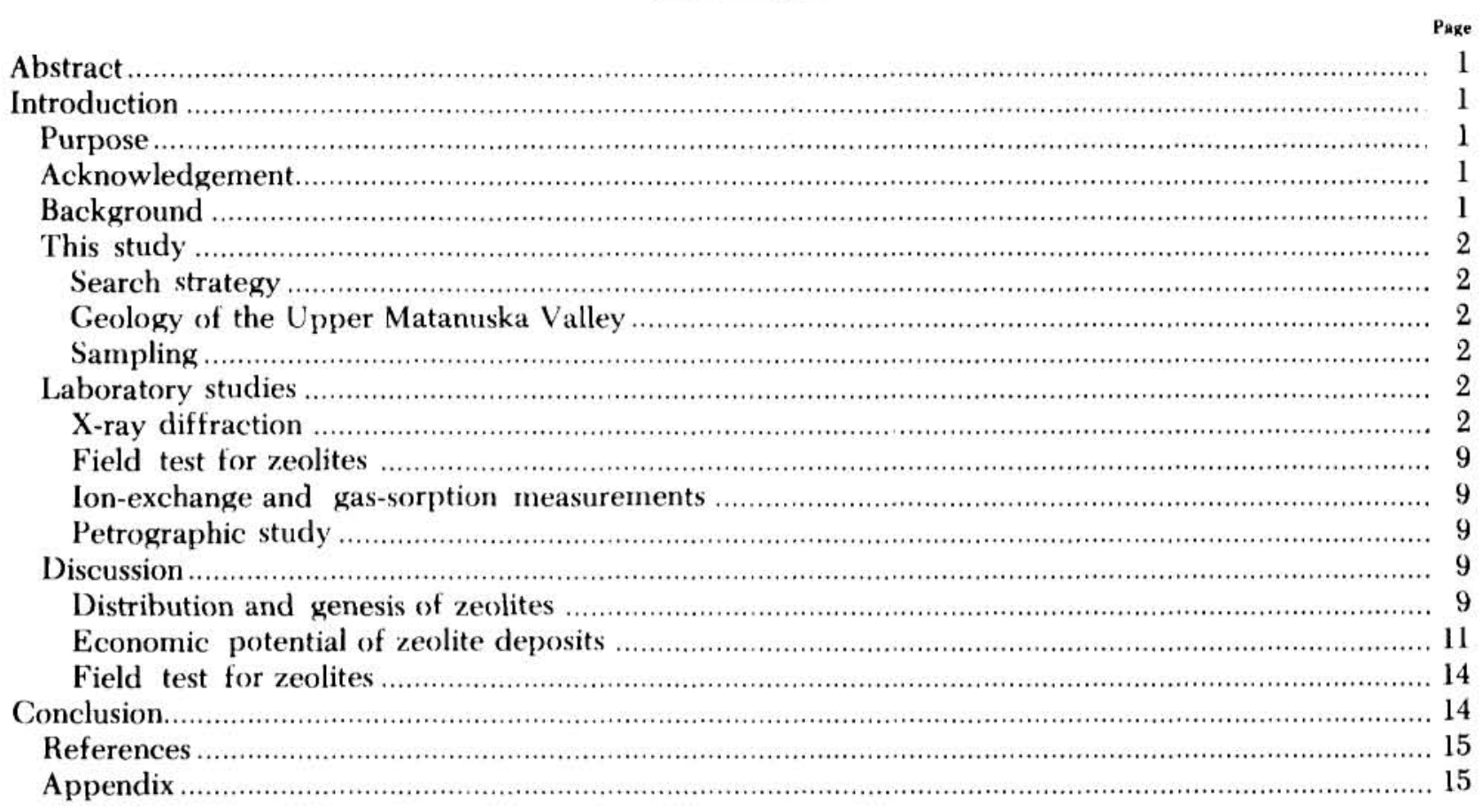

Selected references from Chemical Abstracts on the use and properties of certain natural zeolites

\section{ILLUSTRATIONS}

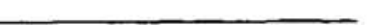

Plate I. Location of areas studied, sample localities and simplified geologic maps of Sheep Mountain, Horn Mountain and Goober Lake areas

Figure 1. Venn diagram showing general conditions necessary for sedimentary zeolite formation and preservation

2. Cross section from Goober Lake north to Horn Mountain showing probable zeolite zonation

3. Possible P-T fields for low-grade mineral facies 


\section{TABLES}

TABLE 1. Sample number, hand specimen description and mineralogy of samples

as determined by $\mathrm{x}$-ray diffraction.

2. Results of chemical test for the presence of zeolites

3. Results of zeolite evaluation, Worcester Polytechnic Institute... 


\title{
SEDIMENTARY ZEOLITE DEPOSITS OF THE UPPER MATANUSKA VALLEY, ALASKA
}

\author{
by I). B. Hawkins
}

\begin{abstract}
ABSTRAC:I
Mordenite, heulandite, and laumontite deposits of possible economic significance exist in the vicinity of Horn Mountain and Sheep Mountain in the upper Matanuska Valley. The mordenite deposit in particular bears further study.

Zeolitization in the area is the result of burial diagenesis and low-grade regional metamorphism. At the time of reolite formation, temperatures and salinities were lower in the Horn Mountain area, where deposits of mordenite and heulandite were formed, than for the laumontite deposits of Sheep Mountain.

A chemical field test for the presence of zeolites was not effective in distinguishing zeolitized from un-zeolitized rocks in the area.
\end{abstract}

\section{INTRODUCTION}

\section{PURPOSE}

The purpose of this study was to investigate the type and extent of zeolitization in the rocks of the Talkeetna and Matanuska formations of the upper Matanuska Valley, and to determine if zeolite deposits of possible economic significance were present. See Plate 1, for the location of the area studied.

\section{ACKNOWLEDGEMENT}

In this work, I am particularly indebted to Arthur M. Grantz of the U. S. Geological Survey who freely shared his special knowledge of the zeolite occurrence in the upper Matanuska Valley with me, and in particular for bringing to my attention the tuffs of the Horn Mountain area (see Plate 1). I also wish to thank Professor Leonard Sand of Worcester Polytechnic Institute, who, as a professional courtesy, evaluated several of the zeolite samples for me. I also wish to thank my colleague, Dr. Donald Grybeck for his helpful criticism of this report. Finally, I wish to thank Mr. William Fackler, Dr. Thomas E. Smith, Dr. Thomas Mowatt and Namok Veach of the Alaska State Division of Geological and Geophysical Surveys for the funding and analytical support of this work.

\section{BACKGROUND}

Zeolites are hydrous alumino-silicate minerals structurally related to the feldspars and containing alkali or alkaline-earth ions. The zeolites are unique in that the alumino-silicate framework is so constructed that large channelways and cavities are present within the structure. The alkali and alkaline-earth cations and water molecules which occupy structural positions within these channels and cavities are readily replaceable by other ions or molecules. Because the channels have unique aperture dimensions, only ions and molecules of the appropriate size can enter the structure. Because of these properties, zeolites serve as ion exchangers, gas sorbents, and molecular sieves to name a few applications. The references at the end of this report and especially those listed in Appendix 1 indicate the uses to which zeolites are put.

In the United States, most of the uses are filled by synthetic zeolites. The natural zeolites are extensively used in other countries; in Japan for example, the exploitation of natural zeolites is a multi-million dollar industry.

Zeolites formerly were thought to be rather rare minerals occurring as vug fillings in volcanic rocks. It was not until the mid 1950's to early 1960 's that zeolites were shown to be very common sedimentary minerals of ten formed as the result of the alteration of vitric tuffs in saline-lake environments. The numerous large deposits of sedimentary zeolites in the conterminous United States were formed in tisis manner (Shepard, 1971; Papke, 1972). The zeolite deposits of Japan however, formed as a result of the interaction of marine waters on volcanic materials (Utada, 1971). The zeolites respond quite readily to changes in temperature and pressure as a result of burial. These changes produce characteristic suites of zeolites and other minerals which have come to be recognized as the zeolite facies of metamorphism (Coombs, 1970). Because the zeolites are relatively unstable, over a sufficiently long period of time, they may alter to more stable minerals such as the 
feldspars. Zeolite deposits are thus confined to relatively young rocks. The conditions for the formation and preservation of the sedimentary zeolites are:

1. Reactive parent material, e.g., vitric tuffs;

2. Fluids of the appropriate chemical composition, e.g., saline-lake water;

3. Time sufficient for the formation of zeolites but not so long that the zeolites formed have been transformed to more stable minerals, e.g., Mesozoic to present.

These conditions are shown schematically in Venn diagram form in Figure 1.

\section{THIS STUDY}

\section{SEARCH STRATEGY}

In searching for zeolite deposits of potential economic importance in Alaska, the zeolite deposits of Japan, formed by alteration of volcanic rocks in a marine environment, serve as an excellent guide. The model offered by the zeolite deposits of the conterminous United States is not applicable to Alaska because unlike the western United States, Alaska did not have extensive Tertiary lake basins in which volcanic detritus was deposited. Using the conditions of Figure 1 as a guide, attention was directed to the Talkeetna formation in the upper Matanuska Valley. A literature search pertaining to the area revealed that zeolites had long been known to be present in this area (Capps, 1927; Grantz, 1965). Parenthetically, using the same model Madonna (1973) has discovered two previously unreported zeolite deposits in Alaska, one of which is of potential economic significance.

\section{GEOLOGY OF THE UPPEK MATANUSKA VAL,L.EY}

The geology of the area studied has been described by (apps (1927) and more recently by Granty (1965). The geoleggy of the gypsum deposits on Sheep Momitain has beendescribed by Eckhart (1951).

The present study was limited to investigating zeolitization in the lower Jurassice Talkecetnat formation and lower mits of the upper (Cretaceous Matanuska formation. In the atreat studied, the Talkeetna formation consists of primary and reworked volcanic ejecta and lavas of andesitic and basaltic composition; mostly marine, partly nonmarine. The formation consists of thick units of marine pyroclastic sandstone, siltstone and claystone (coarse and fine-grained, water-laid tuffs). The rocks of the Talkeetna formation are commonly somewhat altered to chlorite, clay minerals, zeolites and albite. At Sheep Mountain and vicinity strong hydrothermal activity has produced greenstone.

The Matanuska formation consists of claystones, siltstones, shales and sandstones with limestone concretions and lentils. Prismatic shells of the pelecypod Inoceramus are present in some units. Basal units consist of pebbly epiclastic volcanic sandstone with marine fossils, limestone concretions and wood fragments (Grant\%, 1965).

\section{SAMPIING;}

Samples of fist-sized dimensions were collected mainly from numerous outcrops of the Talkeetna formation at three areas in the upper Matanuska Valley. To a lesser extent outcrops of volcanic sandstones of the Matanuska formation were sampled as well. (See Plate 1 for the location of the sample areas). Plate 1 shows the localities from which samples were collected. In sampling these areas particular attention was paid to sample vesicular volcanics, vein material and tuffs, as these materials are likely to contain zeolites.

As can be seen in Plate 1, the Sheep Mountain area was most extensively sampled, primarily because of the accessibility of the area and because no information was available a priori to suggest that zeolitization in the Horn Mountain and Goober Lake areas was any different from that expected at Sheep Mountain.

\section{LABORATORY STUDIES X-RAY DIFFRACTION}

P'ortions of the samples collected were ground in an agate mortar, mixed with distilled water to form a slurry and spread on a glass microseope slide. Xras diftraction patterns of these slides were obtaned using Ni filtered ( 11 Ka radiation at a scan speed of two degrees two-theta per minute. Diffraction peaks over the angular range between four degrees to forty degreess two-theta were recorded. The x-ray diftraction patterns of the samples were compared with $x$-ray diffraction 


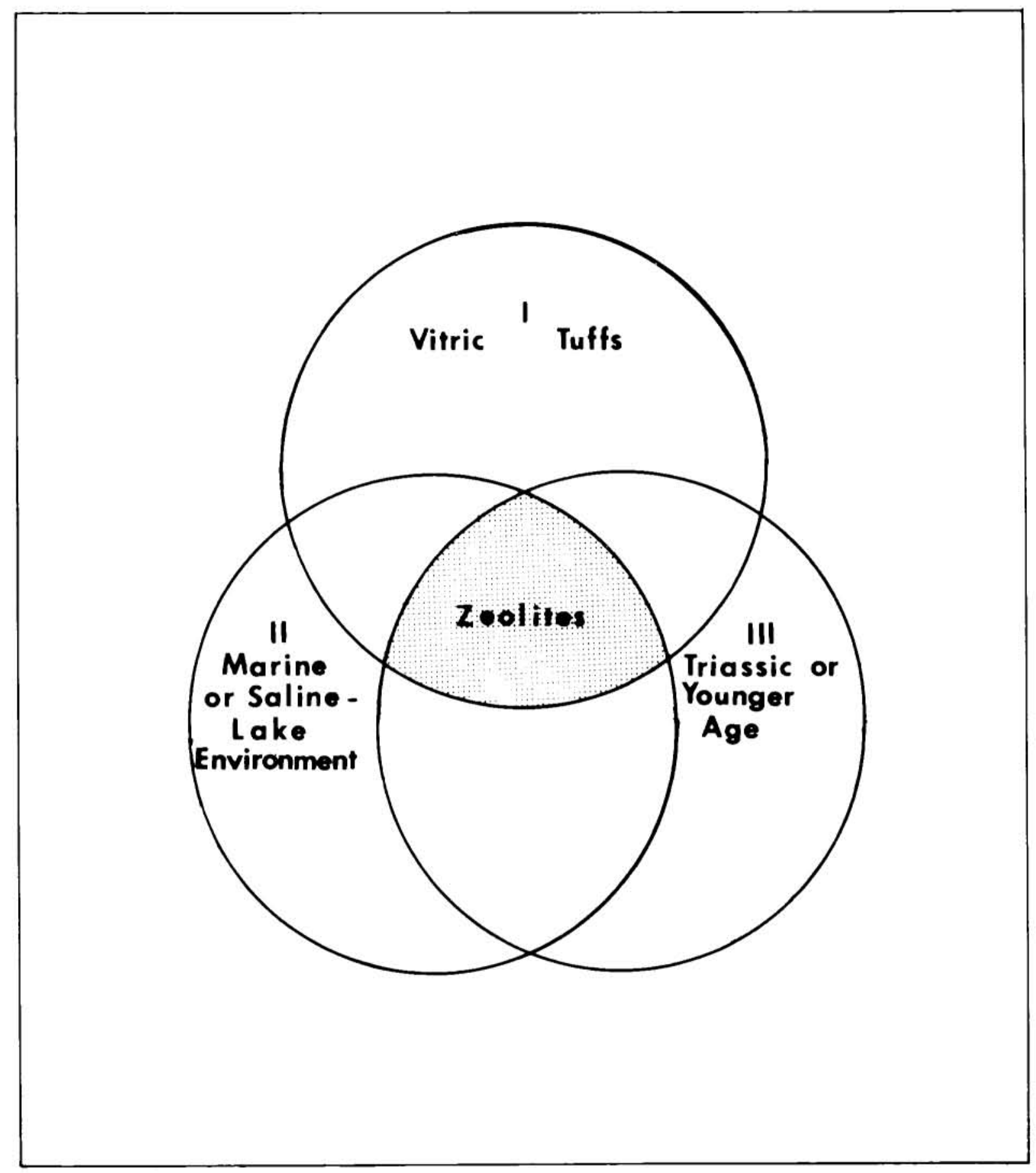

Figure 1. Venn diagram showing general conditions necessary for sedimentary zeolite formation and preservation. 
TABLE 1. Sample number, hand-specimen description and mineralogy of samples as determined by X-ray diffraction. See Figures 3, 4, and 5 for the localities from which these samples were taken.

\begin{tabular}{|c|c|c|}
\hline $\begin{array}{l}\text { Sample } \\
\text { Number }\end{array}$ & Description & $\begin{array}{c}\text { Mineralogy } \\
\text { (zeolites are indicated in bold faced type) }\end{array}$ \\
\hline 1 & Massive, volcanic & Quartz, feldspar, chlorite \\
\hline 2 & Volcanic breceia & Quart\%, laumontite, chlorite \\
\hline 3 & Water-laid tuff & Quartz, laumontite \\
\hline 4 & Altered volcanic breccia & Quartz, laumontite, feldspar \\
\hline 5 & Fine-grained volcanic sandstone & Quartz, laumontite, chlorite \\
\hline 6 & Massive volcanic & Quartz, chlorite, feldspar \\
\hline 7 & Water-laid tuff(i) & Quartz, laumontite, chlorite, feldspar \\
\hline 8 & Massive volcanic & Quartz, laumontite, chlorite, feldspar \\
\hline 9 & Vein filling in massive volcanic & Calcite, laumontite, chlorite \\
\hline 10 & Fractured, vein bearing volcanic & Calcite, chlorite, feldspar \\
\hline 11 & Fractured, vein bearing volcanic & Quartz, laumontite, feldspar \\
\hline 12 & Massive volcanic & Quartz, chlorite, feldspar \\
\hline 13 & Dense, volcano-clastic & Quartz, laumontite, feldspar \\
\hline 14 & Claystone & Quart7, chlorite, feldspar \\
\hline 15 & Vein bearing, fractured volcanic & $\begin{array}{l}\text { Quart\%, laumontite, calcite, chlorite. } \\
\text { feldspar }\end{array}$ \\
\hline 16 & Vein filling from fractured volcanic & Quartz, laumontite, feldspar \\
\hline 17 & Water-laid tuff & Quart7, chlorite, epidote (?) \\
\hline 18 & Vein bearing fractured volcanic & $\begin{array}{l}\text { Quartz. laumontite, chlorite, calcite, } \\
\text { feldspar }\end{array}$ \\
\hline 19 & Massive volcanic & C.hlorite, feldspar \\
\hline 20) & Vein-bearing tutf & Quart», laumontite, chlorite, calcite \\
\hline 21 & Vein-bearing, fractured tuff & Laumontite, chlorite, feldspar \\
\hline 22 & Fracture, vein-bearing siltstone & Quartz, laumontite, chlorite, datolite \\
\hline 23 & Altered claystone & Quartz, kaolinite, calcite \\
\hline $24 a$ & Vein filling & Quart\%, calcite \\
\hline $24 \mathrm{~b}$ & Altered pebbly breccia & Quartz, kaolinite, calcite, feldspar \\
\hline $24 \mathrm{c}$ & Vein-bearing, massive volcanic & Calcite, unidentified major phase \\
\hline 25 & Vein-bearing, massive volcanic & Quartz, laumontite, calcite, feldspar \\
\hline
\end{tabular}


Table 1. - Continued

\begin{tabular}{|c|c|c|}
\hline $\begin{array}{l}\text { Sample: } \\
\text { Number }\end{array}$ & Description & $\begin{array}{c}\text { Mineralogy } \\
\text { (zeolites are indicated in bold faced type) }\end{array}$ \\
\hline 26 & Siltstone & Quart $\%$ calcite, kaolinite \\
\hline 27 & Tuff & Quartz, laumontite, chlorite \\
\hline 28 & Tuff & Quart\%, laumontite, feldspar \\
\hline 29 & T'uft & Quartz, laumontite, feldspar \\
\hline 30) & luff & Quartz, laumontite, teldspar \\
\hline 31 & Claystone & $\begin{array}{l}\text { Quartz, laumontite, kaslin(?), calcite, } \\
\text { feldspar }\end{array}$ \\
\hline 32 & Pumice and tuff & Quartz, laumontite, chlorite \\
\hline 33 & Massive volcanic & Quart», chlorite, feldspar, calcite \\
\hline 34 & Massive volcanic & Quar», kaolinite, teldspar \\
\hline 35 & Fractured, massive voleanic & Quartz, laumontite, chlorite, feldspar \\
\hline 36 & Massive voleanic & Quartz, chlorite, teldspar \\
\hline 37 & Siltstone & Quartz, calcite, chlorite, teldspar \\
\hline 38 & ('ypsum & Gypsum \\
\hline 39 & ('уруыни & Gypsum \\
\hline 40) & Fractured, vein-bearing volcanic & Quartz, laumontite, chlorite, gypsum \\
\hline $41 \mathrm{a}$ & Vein filling, altered volcanic & Gypsum, laumontite, chlorite \\
\hline $41 \mathrm{~b}$ & Vein filling, altered volcanic & Gypsum, chlorite \\
\hline 42 & Greenstone & Epidote, calcite \\
\hline 43 & Conglomerate & Quart\%, laumontite \\
\hline 44 & Greenstone & Quart\%, chlorite, epidote \\
\hline 45 & Conglomerate & Quart\%, feldspar \\
\hline $46 a$ & Vein-bearing fractured volcanic & Laumontite, chlorite, feldspar \\
\hline $46 b$ & Hydrothermally altered fractured volcanic & Quartz, laumontite, teldspar, kaolinite \\
\hline 47 & Vein-bearing fractured volcanic & Quartz, laumontite, feldspar \\
\hline 48 & Volcanic sandstone & Quart\%, laumontite, feldspar \\
\hline 49 & Coarse volcanic sandstone & Quartz, laumontite, chlorite, feldspar \\
\hline 50 & Vein-bearing fractured volcanic & Quartz, laumontite, chlorite, feldspar \\
\hline 51 & Tuff & Quart\%, laumontite, feldspar, chlorite \\
\hline 52 & Greenstone & Prehnite \\
\hline 53 & Volcanic sandstone & Quartz, laumontite, chlorite, feldspar \\
\hline $54 \mathrm{a}$ & Volcanic sandstone & Quartz, chlorite \\
\hline $54 \mathrm{~b}$ & Hydrothermally altered massive volcanic & Quartz, chlorite \\
\hline
\end{tabular}


Table 1. - Continued

\begin{tabular}{|c|c|c|}
\hline $\begin{array}{l}\text { Sample } \\
\text { Number }\end{array}$ & Description & $\begin{array}{c}\text { Mineralogy } \\
\text { (zeolites are indicated in bold faced type) }\end{array}$ \\
\hline $54 \mathrm{c}$ & Red-brown soil, from massive volcanic & Quartz, chlorite, calcite \\
\hline 55 & Conglomeratic greenstone & Quartz, laumontite, feldspar, kaolinite \\
\hline 56 & Vein-bearing fractured volcanic & Quartz, laumontite \\
\hline 57 & Claystone & Sericite \\
\hline 58 & Vesicular volcanic & Quartz, laumontite \\
\hline 59 & Tuffaceous sandstone & Quartz, laumontite \\
\hline 60 & $\begin{array}{l}\text { Volcanic gouge with zeolite(?) } \\
\text { porphyroblasts }\end{array}$ & Quartz, laumontite, teldspar \\
\hline 61 & Coarse volcanic sandstone & Laumontite, chlorite, feldspar \\
\hline 62 & Clayey gouge & Quart\%, laumontite, chlorite \\
\hline 63 & $\begin{array}{l}\text { Vesicular volcanic with zeolite(?) } \\
\text { vug fillings }\end{array}$ & Quart7, laumontite, feldspar \\
\hline 64 & Tuff and pumice & Quartz, laumontite, chlorite, feldspar \\
\hline 65 & Massive volcanic & Quartz, laumontite, chlorite \\
\hline 66 & Massive volcanic & Quartz, laumontite, chlorite, feldspar \\
\hline 67 & Tuff & Prehnite \\
\hline $68 \mathrm{a}$ & Vesicular volcanic & Chlorite, epidote \\
\hline $68 \mathrm{~b}$ & Vesicular volcanic & Quartz, chlorite, epidote \\
\hline $69 \mathrm{a}$ & Massive volcanic & Quartz, chlorite \\
\hline $69 b$ & $\begin{array}{l}\text { Vesicular volcanic with zeolite(?) } \\
\text { vug fillings }\end{array}$ & Wairakite (?), chlorite \\
\hline $69 c$ & Quartz sericite rock & Quartz, sericite, chlorite, feldspar \\
\hline $70 \mathrm{a}$ & Massive andesite(?) & Chlorite, feldspar \\
\hline $70 \mathrm{~b}$ & $\begin{array}{l}\text { Hydrothermally altered andesite( }(?) \\
\text { with marcasite blebs }\end{array}$ & Quartz, chlorite, sericite \\
\hline $70 \mathrm{c}$ & Tuff, float & Quartz, epidote \\
\hline $70 \mathrm{~d}$ & $\begin{array}{l}\text { Vesicular, volcanic float, with quartz(?) } \\
\text { vug fillings }\end{array}$ & Quartz, chlorite, feldspar \\
\hline $70 \mathrm{e}$ & Vein-bearing fractured volcanic & Quartz, laumontite \\
\hline $70 \mathrm{f}$ & $\begin{array}{l}\text { Vesicular volcanic float, with zeolite(?) } \\
\text { vug fillings }\end{array}$ & Wairakite(?), laumontite \\
\hline $71 \mathrm{a}$ & Massive andesite( $(\mathfrak{P})$ float & Quartz., laumontite, chlorite, feldspar \\
\hline $71 \mathrm{~b}$ & T'uff, float & Quartz, chlorite \\
\hline $72 \mathrm{a}$ & Volcanic conglomerate & Quartz, laumontite, feldspar \\
\hline
\end{tabular}




\section{Table 1. - Continued}

\begin{tabular}{|c|c|c|}
\hline $\begin{array}{l}\text { Sample } \\
\text { Number }\end{array}$ & 1)escription & $\begin{array}{c}\text { Mineralogy } \\
\text { (zeolites are indicated in bold faced type) }\end{array}$ \\
\hline $72 b$ & Massive volcanic & Quartz, laumontite, teldspar \\
\hline 73 & Vein-bearing tutf & Quartz, laumontite, chlorite, feldspar \\
\hline $74 a$ & Massive voleanic & Quart\%, laumontite, chlorite, teldspar \\
\hline $74 \mathrm{~b}$ & Massive volcanic & Gypsum, chlorite \\
\hline $74 \mathrm{c}$ & Vein-bearing volcanic & Gypsum \\
\hline 75 & Vein-bearing fractured voleanic & Quartz., laumontite \\
\hline 76 & Massive volcanic & Quartz, chlorite, feldspar \\
\hline 77 & Punice & $\begin{array}{l}\text { Kaolinite, wairakite(r), laumontite, } \\
\text { feldspar }\end{array}$ \\
\hline $78 \mathrm{a}$ & Gypsiferous rock and clay & Gypsum, quartz, feldspar \\
\hline $78 \mathrm{~b}$ & Punice & Gypsum, epidote \\
\hline 79 & Vesicular basalt, with zeolite vug fillings & Laumontite, chlorite, epidote \\
\hline 80 & Vein quartz with malachite and chalcopyrite & Quartz, chalcopyrite \\
\hline $81 \mathrm{a}$ & Vesicular volcanic with zerolite vug fillings & Laumontite \\
\hline $8 \mathrm{Ib}$ & Vein and fug filling from massive volcanic & Laumontite \\
\hline $81 \mathrm{c}$ & Vein and vug filling from massive volcanic & Laumontite \\
\hline 82 & Vesicular volcanic with zeolite vug fillings & Laumontite \\
\hline 83 & Tuff & Quartz \\
\hline 84 & Tuff & Quartz, laumontite, chlorite \\
\hline 85 & Massive volcanic, float & Quartz, laumontite, chlorite, feldspar \\
\hline 86 & Vesicular volcanic & Quartz., prehnite \\
\hline 87 & $\begin{array}{l}\text { Vein filling from massive } \\
\text { volcanic }\end{array}$ & $\begin{array}{l}\text { Quartz, laumonite, chlorite, feldspar. } \\
\text { calcite }\end{array}$ \\
\hline $88 a$ & Massive volcanic & Laumontite, chlorite, feldspar \\
\hline $88 \mathrm{~b}$ & Greenstone & Chlorite, epidote, feldspar \\
\hline 89 & Massive volcanic & Quartz, laumontite, chlorite \\
\hline 90 & Massive volcanic & Wairakite(?), sericite, kaolinite, quartz. \\
\hline 91 & Volcanic sandstone, float & Quartz, prehnite, chlorite \\
\hline 92 & T'uff & Quartz, laumontite, chlorite \\
\hline 93 & Tuff, float & Quartz, laumonite, chlorite \\
\hline
\end{tabular}


Table 1. - Continued

\begin{tabular}{|c|c|c|}
\hline $\begin{array}{l}\text { Sample } \\
\text { Number }\end{array}$ & Description & $\begin{array}{c}\text { Mineralogy } \\
\text { (zeolites are indicated in bold faced type) }\end{array}$ \\
\hline 94 & Precipitate on stream cobble & Amorphous to $\mathrm{x}$-rays \\
\hline 95 & Vesicular volcanic & Quartz, laumontite, chlorite, feldspar \\
\hline 96 & Massive volcanic & $\begin{array}{l}\text { Laumontite, wairakite(?), chlorite, } \\
\text { feldspar }\end{array}$ \\
\hline 97 & Massive volcanic & Quartz, laumontite \\
\hline 98 & Tuff & Quartz, wairakite (?), chlorite, feldspar \\
\hline 99 & Tuff & Quartz, laumontite, chlorite \\
\hline 100 & Tuff & Quartz, laumontite, chlorite, feldspar \\
\hline 101 & Tuff & Quartz, laumontite, chlorite, feldspar \\
\hline 102 & Tuff & Quartz, laumontite, chlorite, feldspar \\
\hline 103 & Pumice tuff & Quartz, laumontite, chlorite, feldspar \\
\hline 104 & Massive volcanic & Quartz, laumontite, chlorite, feldspar \\
\hline 10.5 & Tuff & Quartz, laumontite \\
\hline 106 & Tuff & Quartz, laumontite, chlorite, feldspar \\
\hline 107 & Vein-bearing fractured volcanic & Quartz, laumontite, chlorite, feldspar \\
\hline 108 & Vesicular volcanic & Feldspar, chlorite \\
\hline 109 & Tuff & Quart々, laumontite, chlorite, feldspar \\
\hline 110 & Massive volcanic & Quart\%, laumontite \\
\hline 111 & Pebbly volcanic sandstone & Mordenite \\
\hline $112 \mathrm{a}$ & Volcanic sandstone & Mordenite \\
\hline $112 \mathrm{~b}$ & Volcanic sandstone & Mordenite \\
\hline 113 & Tuff, float & Mordenite \\
\hline 114 & Tuff & Laumontite \\
\hline 115 & Tuff with zeolite veinlets & Heulandite \\
\hline 116 & Tuff & Mordenite \\
\hline 117 & Vug filling, vesicular andesite(?) & Heulandite \\
\hline 118 & Tuff. & Heulandite \\
\hline 119 & Tuff & Mordenite \\
\hline 120 & Tuff, float & Quartz, laumontite, chlorite, feldspar \\
\hline 121 & Tuft, float & Quartz, laumontite, feldspar \\
\hline 122 & Volcanic sandstone & Quartz, chlorite, feldspar \\
\hline 123 & Volcanic sandstone & Quartz, feldspar \\
\hline 124 & Vein-bearing volcanic sandstone & Quartz, calcite, possible wairakite(?) \\
\hline 125 & Pebbly volcanic sandstone & Quartz, chlorite \\
\hline
\end{tabular}


patterns of a number of zeolites and common rock forming minerals to determine the gross mineralogy of the samples.

Those samples which contained zeolites of the heulandite-clinoptilolite group were heated following the method given in Alietti (1972) to distinguish between heulandite and clinoptilolite. The results of the $x$-ray diffraction and heattreatment studies are given in Table 1.

\section{FIELI) TEST FOK ZEOIITES}

Helfferich (1964) suggested a simple chemical test for the presence of zeolites. This test depends upon the ion-exclusion properties of zeolites and a hydrolysis reaction which is ultimately manifested as a pronounced increase in $\mathrm{pH}$ of the test solution. According to Helfferich, pH values of 9 to 11 are indicative of the presence of zeolites.

As recommended by llelfferich, tetra butyl ammonium bromide solutions were used to lessen interference with the test by the layer silicates. Measurements of $\mathrm{pH}$ were carried out using a combination microelectrode and a Beckman Model $\mathrm{N} \mathrm{pH}$ Meter. The results of this test are shown in Table 2.

\section{ION-EXCIIANGEA A I) GAS-SORPTION MEASUREMENTS}

Following the $x$-ray diffraction analysis, four zeolite-bearing samples were sent to P'rof. Leonard Sand of Worcester Polytechnic Institute (W.P.I.) for evaluation of their ion-exchange and gas sorptive properties. The results of these analyses are shown in Table 3, along with those for a synthetic sodium mordenite for comparison. Also shown in Table 3 are the results of a heat-of-wetting test which serves as the basis for a proposed new field test for zeolites (.Culfaz, Keisling and Sand, 1973).

\section{PFTROGRAPHIC: STUIDY}

Thin sections were prepared of the samples sent to W.P.I. to determine the mode of occurrence of the zeolites in these samples. Time did not permit a more extensive petrographic study. The results of this study are presented and discussed in the following section on the mode of occurrence of zeolites.

\section{DISCUSSION}

\section{DISTRIBUTION ANI) GENESIS OF ZEOLITES}

From Table 1, it is evident that many of the samples collected are zeolite bearing. Most of the samples collected from the Sheep Mountain area contained laumontite or its dehydration product, leonhardite. Laumontite (leonhardite) occurs in vugs and veins in fractured massive volcanics and as an alteration product of vitric tuffs.

A few samples from the Sheep Mountain area contained an analcime-group mineral tentatively identified as wairakite(?). It was not possible to distinguish between the sodium zeolite analcime and its calcium analog wairakite by means of $x$-ray diffraction. A thin section of this material (sample $\# 98$ ) revealed a mass of weakly birefringent fine grained zeolite as an alteration product of the felsic ground mass of an andesite(?). The birefringence of this material, plus the calcium rich nature of this rock and the zeolites and other minerals in the area suggests that wairakite rather than analcime is present. A much more detailed study involving mineral separation, chemical analysis and detailed petrographic and $x$-ray diffraction studies is needed before this zeolite can be identified unequivocally.

The layer silicate prehnite, a common associate of calcic zeolites, was detected in several samples from Sheep Mountain. No pumpellyite was observed. Chlorite was a nearly ubiquitous mineral in the samples from Sheep Mountain.

In contrast to the zeolite assemblage at Sheep Mountain, the samples from the Horn Mountain area (see figure 4) bore the zeolites mordenite and heulandite. Laumontite was present in one sample of tuff from Albert Creek. Neither prehnite nor wairakite were observed in these samples.

In the Horn Mountain area, mordenite occurs as an alteration product of the volcanic sandstones of the Matanuska formation (samples 111, 112a and $112 \mathrm{~b}$ ) and replacing glassy shards in the finegrained vitric tuffs at the head of Albert Creek (samples 113, 116 and 119).

Heulandite is present as thin, tabular crystals in veins in an altered siliceous volcanic in Albert Creek (sample 115) and as large $(1-2 \mathrm{~cm}$ ) foliate aggregates in vug fillings of the massive volcanics of Horn Mountain (sample 117). Heulandite also occurs in an altered tuff, where it appears to have formed at the expense of the glass (sample 118). 
$1<$

\section{Mordenite-Heulandite Zone}

$?--$

Horn Mountain

Syncline Mountain

1

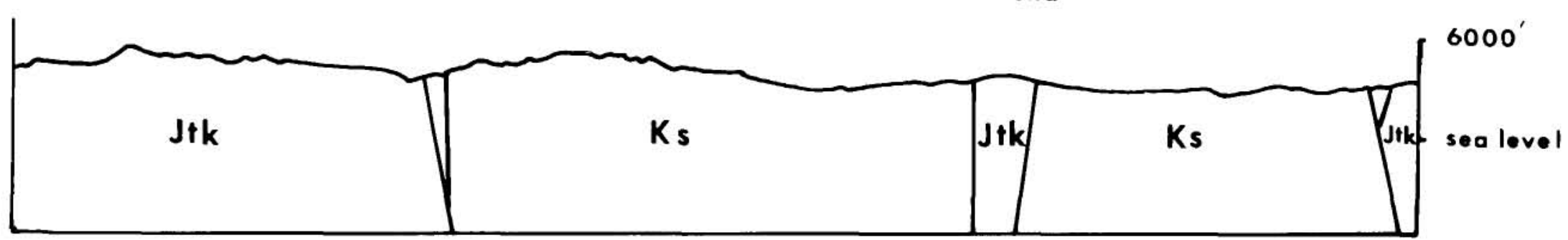

\section{Laumontite-Wairakite(?) Zone}<smiles>CCCC</smiles>

Sheep Mountain

$$
\text { (east end) }
$$

Goober Lake

Figure 2. Cross section from near Goober Lake north to Horn Mountain showing probable zeolite zonation. See Plate 1 for areal relations and lithology. Cross section greatly simplified from section C-C' of Grantz (1965). 
Laumontite occurs in an altered tuff (sample 114) on Albert Creek. This laumontized tuff appears similar to those of the Sheep Mountain area.

The samples from the Goober Lake area (See Plate 1) are for the most part unzeolitized. One sample (124) may contain an analcime-like zeolite, however.

The zeolite distribution of the areas sampled is shown schematically in cross section in Figure 2.

The different zeolite assemblages at Horn Mountain and Sheep Mountain are indicative of different conditions that prevailed at the time of zeolite formation. As shown in Figure 3, the mordenite-heulandite assemblage is typical of low temperatures and low partial-pressures of water $\left(\mathrm{P}_{\left.\mathrm{H}_{20}\right)}\right)$. Laumontite and laumontite-prehnite are characteristic of higher pressure-temperature conditions. The important variable in these zeolite stability relations is the chemical potential of water as Zen (1960) has shown. The more hydrous heulandite $\left(\mathrm{CaAl}_{2} \mathrm{Si}_{7}{ }_{18} \cdot 6 \mathrm{H}_{2} \mathrm{O}\right)$ and mordenite $\left(\mathrm{CaAl}_{2} \mathrm{Si}_{10} \mathrm{O}_{24} .7 \mathrm{H}_{2} 0\right)$ assemblage is stable under a higher chemical potential of water than are the less hydrous zeolites laumontite $\left(\mathrm{CaAl}_{2} \mathrm{Si}_{4} \mathrm{O}_{12}, 4 \mathrm{H}_{2} 0\right)$ and wairakite $\left(\mathrm{CaAl}_{2} \mathrm{Si}_{4} \mathrm{O}_{12} 2 \mathrm{H}_{2} \mathrm{O}\right)$. The chemical potential of water may be varied (A) by altering the partial pressure of water on the system; or (B) by varying the salinity of the aqueous fluid. Increasing salinity of intra stratal waters at depth has the same effect as increasing temperature in promoting a zonation from more hydrous to less hydrous phases.

From the discussion above, the zeolites of the Horn Mountain area formed under lower temperature or salinity conditions than did those of the Sheep Mountain area. Sea-water reactions contemporaneous with the cooling of the submarine volcanics of the Talkeetna formation could have contributed to the zeolitization of these rocks. However, because the zeolitization extends to the basal volcanic sands of the Matanuska formation, it is more likely that reactions involving burial diagenesis and regional metamorphism are the cause of zeolitization. The zonation discussed above suggests that the volcanics and volcanic sands at Horn Mountain and vicinity were not as deeply buried as were the volcanics at Sheep Mountain.

Zeolitization of the Sheep Mountain area does not appear to be related to the intrusive that has so obviously hydrothermally altered the area (see greenstone area, Plate 1). Neither the laumontite nor prehnite, nor wairakite(?) distributions bear any obvious relation to the intrusive.

\section{FCONOMIC: POTENTIAL, OF ZEOLITE DEPOSITS}

The mordenite-bearing tuffs in the vicinity of Horn Mountain may be of economic importance (Plate 1). Although the tuff from which the mordenite bearing samples was obtained appears to form an extensive series of outcrops along the low ridge to the north of Albert Creek, it is emphasized that neither the extent nor grade of these tuffs is known at present.

As shown in T'able 3 , the mordenite-bearing tuff sample has a sulfur dioxide sorptive capacity approaching that of the synthetic mordenite. It also exhibits a reasonably high cation exchange capacity, and the highest surface area of the samples submitted although much less than that of the synthetic mordenite. These properties and the location of this deposit near the coal fields of the upper Matanuska Valley, the agricultural lands of the lower Matanuska Valley, the oil fields of the Cook Inlet area, and the population center of Anchorage suggest several potential uses: (A) sulfur dioxide sorbent in coal-fired power plants; (B) sorbent for the storage of natural gas from Cook Inlet (Munson and Clifton, 1971); (C) catalysts or catalytic carriers for the hydrocracking of petroleum; (I) conditioner for agricultural soils (Alaska State Division Geol. and Geophys. Surveys, 1973); (E) ion exchange medium for various waste disposal operations including the treatment of municipal sewage and the decontamination of radioactive wastes from future nuclear power plants. It is stressed that these applications are highly speculative and depend upon determining the extent and grade of the mordenite deposits, determining the usefulness of the tuff for different applications and then establishing a market for this material for particular applications.

The laumontite tuffs of Sheep Mountain, while extensive, are probably not as economically important as the mordenite tuff. Laumontite does not have the chenical stability of mordenite, nor does it have the catalytic properties of the higher silica zeolite. However, the laumontized tuff may have important agricultural uses and should not be ignored.

The heulandite bearing tuff at the head of Albert Creek should be investigated further. Heulandite, and particularly the higher silica variety clinoptilolite, have important industrial applicability (Sheppard, 197lb). The occurrence of heulandite as vug fillings is not economically important. 


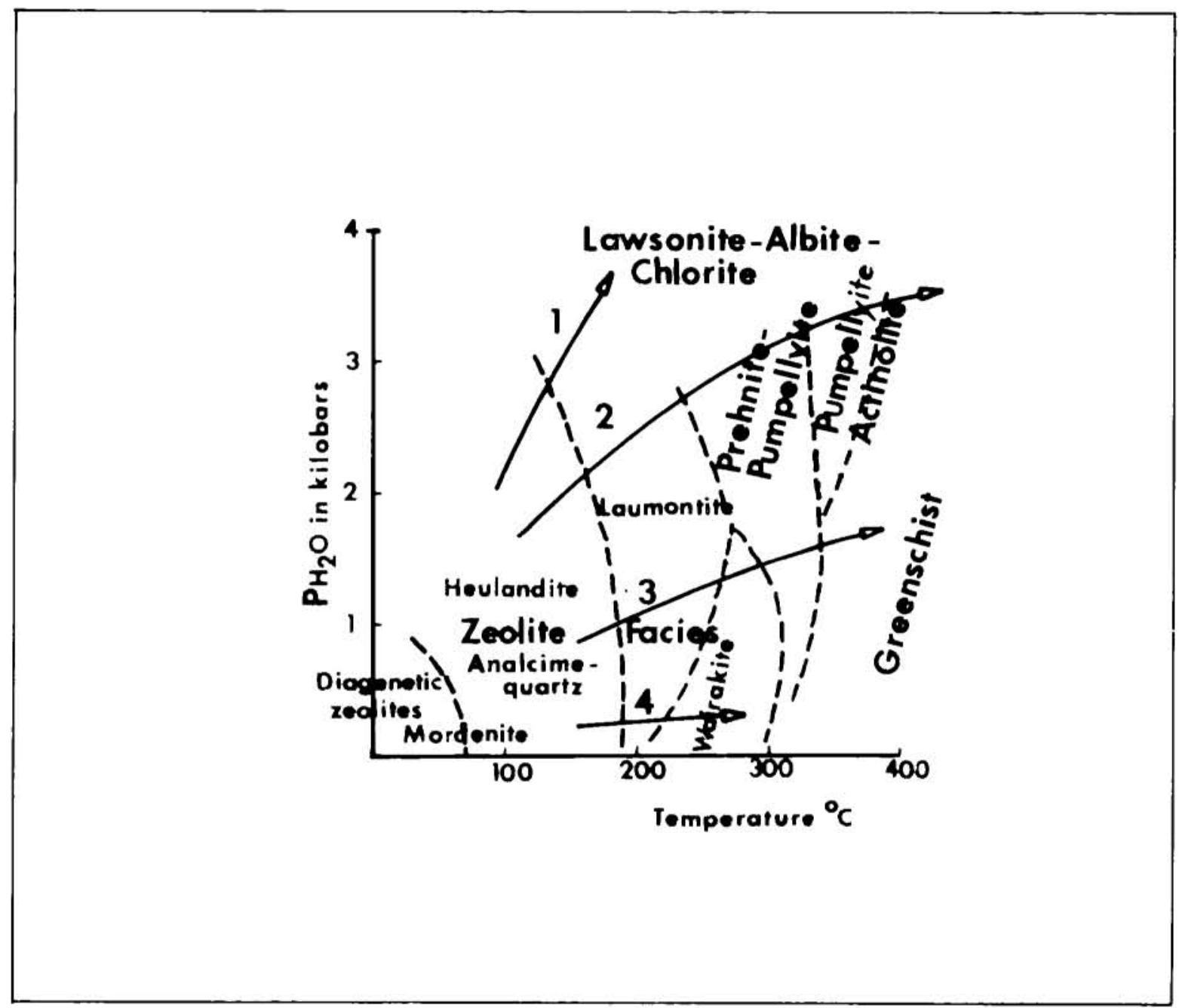

Figune 3. Possible P-T fields for low-grade mineral facies. Arrows represent facies series as follows: (1) High pressure, low temperature; (2) Intermediate; (3) Low pressure intermediate; (4) Lowest pressure. Diagram from Coombs (1970). 
TABLE 2. Results of chemical field test (Helfferich, 1964) for the presence of zeolites.

\begin{tabular}{|c|c|c|}
\hline $\begin{array}{l}\text { Sample } \\
\text { Number }\end{array}$ & $\begin{array}{c}\text { Dominant Mineralogy } \\
\text { (zeolites are indicated in bold faced type) }\end{array}$ & Final $\mathrm{pH}$ \\
\hline 1 & Quart\%, feldspar, chlorite & 10.4 \\
\hline 6 & Quartz, feldspar, chlorite & 10.2 \\
\hline 10) & ('blorite, calcite, feldspar & 10.8 \\
\hline 12 & Quart\%, chlorite, teldspar & 10.4 \\
\hline 19 & Chlorite, teldspar & 10.3 \\
\hline 59 & Quart\%, laumontite & 10.5 \\
\hline $81 \mathrm{a}$ & Laumontite & 10.3 \\
\hline $81 \mathrm{c}$ & Laumontite & 9.9 \\
\hline 86 & Prehnite & 10.8 \\
\hline 90 & Wairakite(?) & 10.2 \\
\hline 91 & Prehnite & 10.0 \\
\hline 96 & Laumontite & 10.8 \\
\hline 97 & Laumontite & 9.2 \\
\hline 98 & Wairakite(?) & 10.4 \\
\hline 99 & Laumontite & 10.1 \\
\hline 110 & Laumontite & 10.5 \\
\hline 111 & Mordenite & 11.0 \\
\hline $112 a$ & Mordenite & 10.0 \\
\hline $112 b$ & Mordenite & 10.9 \\
\hline 113 & Mordenite & 11.3 \\
\hline 114 & Laumontite & 10.9 \\
\hline 115 & Heulandite & 11.2 \\
\hline 116 & Mordenite & 11.2 \\
\hline 118 & Heulandite & 10.5 \\
\hline 123 & Quart\%, feldspar & 9.4 \\
\hline 124 & Calcite, quart\%, feldspar, wairakite (?) & 11.0 \\
\hline 125 & (hlorite, quartz, teldspar & 9.0 \\
\hline
\end{tabular}


T'ABle 3. Results of zeolite evaluation, Worcester Polytechnic Institute.

\begin{tabular}{|c|c|c|c|c|c|}
\hline $\begin{array}{l}\text { Sample } \\
\text { Number }\end{array}$ & Zeolite. & $\begin{array}{l}\text { SO, ( Caplacity } \\
\text { g/ IoO ge dry } \\
\text { Sample. }\end{array}$ & $\begin{array}{l}\text { Ag+ Exchange } \\
\text { Capracity } \\
\text { Mole Kyuiv. } I(0) \text { \& } \\
\text { Sample }\end{array}$ & $\begin{array}{c}\mathrm{N}_{2} \mathrm{BH} / \mathrm{C} \\
\text { Surface Area } \\
\mathrm{m}^{2} / \mathrm{g}\end{array}$ & $\begin{array}{l}\Delta{ }^{\prime} \mathrm{l} \\
{ }^{\circ} \mathrm{C}:\end{array}$ \\
\hline 59 & lammontite & $0.45 \mathrm{~K}$ & 0.1581 & 10.64 & 4.37 \\
\hline 98 & Wairakite(t) & 0.252 & 0.1670 & 21.4 & $4.1: 3$ \\
\hline 116 & Mordenite & 13.188 & 0.1104 & 33.2 & $13.0 \% 3$ \\
\hline 118 & Ilenlandite & 1.9337 & 0.1326 & 16.32 & 6.93 \\
\hline $\begin{array}{l}\text { Synthetic } \\
\text { Na-Mordenite }\end{array}$ & & $1 \times .0$ & ().232 & 432.0 & 16.3 \\
\hline
\end{tabular}

The wairakite(?) occurrence on Sheep Mountain is probably not economic, because of the properties of this zeolite and the sporadic distribution.

The method of establishing mining rights for zeolites on Federal lands has recently been established. The Bureau of Land Management indicates that zeolite deposits are subject to the sodium-potassium leasing law (Papke, 1972).

\section{FIELD TEST FOR ZEOLITES}

The results of the field test evaluation shown in Table 2 indicate that this test is inappropriate for the zeolite samples studied here. The failure of this test to distinguish zeolitized from unzeolitized samples, as shown by the broad range of $p H$ values, is apparently due to the interference of layer silicates on this test.

A new field test for zeolites has just been proposed by Culfaz, Keisling and Sand (1973). This test was performed on the four samples subinitted to W.P.I. for evaluation, the results of which are shown in column 4 of Table 3 . According to the authors, values of $\Delta \mathrm{T}$ in the range 8 to $20^{\circ} \mathrm{C}$ are indicative of an intermediate to high-grade zeolite deposit depending upon the zeolite variety present. Values of $\triangle \mathrm{T}$ greater than $20^{\circ} \mathrm{C}$ are indicative of a high grade chabazite deposit. Note that the mordenite tuff had a $\triangle \mathrm{T}$ value of $13.03^{\circ} \mathrm{C}$ closely approaching that of the synthetic mordenite and suggestive of a high-grade deposit. No other evaluation of this test was made in the present study. It is suggested that this method be investigated further.

\section{CONCLUSIONS}

Zeolite deposits of possible economic significance exist in the upper Matanuska Valley. The mordenite-bearing tuffs at the head of Albert Creek at the east end of Horn Mountain probably have the greatest economic potential. The heulandite-bearing tuffs in this same area and the laumontized tuffs at Sheep Mountain may also be valuable for certain applications. The extent, grade and market value of these deposits must be determined.

Zeolitization of the Sheep Mountain-Horn Mountain area is the result of burial diagenesis and regional metamorphism. The zeolites of the Horn Mountain area formed under conditions of lower temperature and salinity than did those of the Sheep Mountain area. The volcanics of the Sheep Mountain area may have experienced a greater depth-of-burial than did the sediments and volcanics of the Horn Mountain area. Zeolitization of the Sheep Mountain area does not appear to be related to the Sheep Mountain intrusive.

A published field test for zeolites is subject to interference from layer silicates and is inapplicable to the zeolitized rocks of the area studied. A proposed new field test may be applicable and should be investigated. 


\section{REFERENCES}

Alaska State Division of Geological and Geophysical Surveys (1973) Ladd Mountain zeolite deposits could bring agricultural boom; Mines Bull., XXII (5) p. 5.

Alietti, A. (1972) Polymorphism and crystal chemistry of heulandites and clinoptilolites; Am. Min. 57, p. $1448-1462$

Capps, S.R. (1927) Geology of the upper Matanuska Valley, Alaska; I.S. Geol. Survey Bull. 791.

Coombs, D.S. (1970) Present status of the zeolite facies; in Preprints of the Sec. Intn'l. Conf. on Molecular Sieve Zeolites, Worcester Polytechnic Institute, p. 556-566.

Culfaz, A., C.A. Keisling and L.B. Sand (1973) A field test for molecular sieve zeolites. Am. Min. In Press.

Eckhart, R.H. (1951) Gypsiterous deposits on Sheep Mountain, Alaska; U.S. Geol. Survey Bull. 989C:

Grantz, A.M. (1965) Geologic map and cross sections of the Nelchina Area, south central Alaska; U.S. Cieol. Survey (Open File Report.

Helfferich, F, (1964) A simple identification reaction for zeolites (molecular sieves); Am. Min. 49, p. 17531754 .

Madonna, J.A. (197:3) Zeolite occurrences in Alaska; unpublished M.S. thesis, Geology Department, University of Alaska, Fairbanks, Alaska.

Munson, R.A. and R.A. Clifton, Jr. (1971) Natural gas storage with zeolites; U.S. Bur. Mines, Tech. Prog. Rept. 38.

Papke. K.(;. (1972) Erionite and other associated zeolites in Nevada; Nevada Bur. Mines and Geol. Bull. 79.

Sheppard, R.A. (1971a) Zeolites in sedimentary deposits of the United States - a review; in Gould, R.F., ed., Molecular Sieve Zeolites - 1: Am. Chem. Soc., Advances in ('hemistry, ser. 101, p. 279-310.

Sheppard, R.A. (1971b) Clinoptilolite of possible ecomonic value in sedimentary deposits of the conterminous (-nited States; I S. Cieol. Surv Bult 13332-B.

Ltada, M. (1951) /eolite zoning of the Vengene peroclastic rocks in Japan, Scientitic papers of the (iollege of Cineral fiducation, Iniversity of lokyo, 21, p. $189-221$.
Zen, E-an (1961) The zeolite facies; an interpretation; Am. J. Sci. 259, p. 401-409.

\section{Appendix I}

Selected references from Chemical Abstracts on the use and properties of natural zeolites, particularly mordenite, clinoptilolite-heulandite and laumontite.

\section{Ion-Exchange}

Lenzi, G. and A. Pozzuoli (1969) "Behavior of some natural zeolites as a function of the absorption of cesium and strontium in radioactive solutions with low activity." Rend. Accad. Soc. Fis. Nat., Naples, 36 p. 235-249. CA 74-66414.

Mercer, B.W., L.L. Ames and C.J. Touhill (1968) "Ammonia removal from waste water by selective ion-exchange." Amer. Chem. So. Div. Water and Air Waste Chem. Gen. Pap. 8 (1), p. 97-102. CA 71-116322B.

McDaniel, C.V. and P.K. Maher (1971) "Aqueous cation exchange with crystalline alumina-silicate zeolites." Fr. Patent $1,542,754$. CA 71-95327

Sherry, H.S. (1969) "Ion-exchange properties of zeolites." Ion Exchg. 2 p. 89-133. CA 70-61456.

Barrer, R.M., R. Papadopoulos and L.V.C. Rees (1967) "Exchange of sodium in clinoptilolite by organic cations." J. Inog. Nucl. Chem. 29 (8) p. 2047-63. CA 67$85428 \mathrm{~b}$.

Elia, V., R. Caramazza and E. Drioli (1967) "Electrochemical behavior of inorganic ion-exchange membranes, II. Effect of Grain Size." Ric. Sci. 37 (5) 413-17. CA 67-121815m.

Romanlschuk, H., J.K. Miettinen and P. Kivalo (1966) "Laumontite - a natural ion-exchange mineral with high selectivity for cesium." Suomen Kemistilehti, B, 39 (10) 193-5. CA 66-14336.

Peterson, D.L., F. Helfferich and G.C. Blytas (1965) "Sorption and ion-exchange in sedimentary zeolites." J. Phys. (itum. Solids 26 (5) p. 8:35-48. CA $63-2420 \mathrm{~h}$.

Fyte, W.S. (1951) "Note on base exchange in New Zealand laumontite and natrolite." New Kealand J. Sci. Technol. 32B, . Vo, 5. p. 26-9. CA 45-10436e. 


\section{Gas Sorption}

Torii, K., M. Asaka and H. Yamazaki (1969) "Gas chromatography with natural mordenite as column packing." Kogyo Kagaku Zasahi 72 (3) 66l-4. ('A $71-108684-685$.

Barrer, K.M. and 1).E.W. Vaughan (1969) "Sorption and diffusion of rare gases on heulandite and stilbite." Surf. Sci., 14 (1) p. 77-92. (:A 70-99930h.

Suzuki, F., and N. Takahashi (1969) "Adsorption properties of clinoptilolite, I11. Effect of acid treatment and gas-chromatographic study." Yamagata 1)aiguku Kiyo, Kogaku 10 (2), p. 439-48. ('A 74-1290:37.

Mirsalimov, A.M., S.Z. Muminar, E.A. Aripov and K. S. Arhmedov $(1970)$ "Sorption of water vapor by natural ("zbekistan zeolites." ('zb. Khim. \%h. 14 (5) p. 44-46. C:A 74-78465c:

Barrer, R.M. and B. Coughlan (1967) "Influences of crystal structure on zeolitic $\mathrm{CC}_{2}$ 1. Isotherms and selectivity." Mol. Sieves, Pap. Conf. p. 233-41. CA 70)-62030)

Bykov, V.T', An. Kirginitsov, A.V. Luk'yamov and N. E. Scherbatyuk (1964) "Adsorption of steam on natural zeolites." Materialy Uses. Soreshch. p. Tseolitam., 2nd Leningrad. p. 360-5. CA 65-3035f.

Sameshima, J. (1930) "Sorption of gases by minerals. II. Laumontite." Bull. Chem. Soc. Japan, 5, p. 30310. C.A $25-2079^{3}$.

\section{Dessicants}

Klopp, G, J. Gorog, J. Krolyo, T. Mandy, G. Siposs (1970) "Drying organic liquids." Ger. Pat. 1,272,293. (:A 70-11319g.

Klopp, G., (1964) "Absolutization of organic solvents with clinoptilolite." Hung. Pat. 152,353. CA 64-538d.

\section{Molecular Sieves}

Barrer, R.M. and B. Coughlan (1967) "Molecular sieves derived from clinoptilolite by progressive removal of framework change: Characterization by sorption of carbon dioxide and krypton." Mol. Sieves Pap. Conf., Soc. Chem. Ind. Lond. p. 141-8. CA 70-61441.

Piguzova, L. 1. (1966) "Properties and use of some highly siliceous natural molecular-sieve type zeolites." Prir. Sorbenty. Sb. Dokl. Sess. Nauch. Sov. Sin., 7 zuch Primen. Adsorbentor. Akad. Nauk. SSSK., Vladivostok. p. 166-88. CA 70-23100.
Barrer, R.M. (1968) "Some aspects of molecular sieve science and technology." (Chem. Ind. (London) 36, p. 1203-13. CAA 69-99692m.

Sand, L.B. (1966) "Natural and synthetic zeolites for industrial use." Econ. Geol. Mass. Proc, Conf. Univ. Mass. p. 191- 8 . CA 68-70689j.

Bramer, O, and S. Gueller (1966) "Industrial uses of molecular sieves." Fette, Seifen, Anstrichim., 68 (9), p. 735-40. CA 66-30412.

Barrer, R.M. and M.B. Makki (1964) "Molecular seive sorbents from clinoptilolite." Can. J. Chem. 42 (6) p. 1481-7. C:A 61-2516a.

Bliznakov, G., I Golubova, N. Dimov (1963) "Molecular sieve properties of some Bulgarian zeolites." Godishnik. Sofiskcya. Univ., "KL. Okhridski," Khim. Fak. 57, p. 121-32. C.A 63-10724e

\section{Catalysts}

Yamamoto, N. (1968) "Zeolite catalyst in the petroleum industry." Nendo Kagaku. 8 (3-4) p. 1-9. CA $71-93231$.

(1967) "General purpose support catalyst." Neth. Appl. 6,610,598. ('A 67-15337x.

Papp. J. (1967) "Catalysts and Carriers." Hung. Pat. 153,556. CA 67-55943.

Papp, J. (1971) "Hydromethylation of toluene on clinoptilolite." J. Catal. 23 (2) p. 168-82. CA 75-1178333.

Foucher, W.I)., Jr. (1971) "Waxlike hydrocarbon conversion using clinoptilolite catalysts." U.S. Pat. 3,565,788. (CA 74-114067p.

Sato, M., S. Otami (1970) "Disproportionation of toluene." Ger. ()ffen. 1,813,251. CA 72-66579p.

Chen, N.Y. and P.B. Weisz (1967) "Molecular engineering of some shape selective catalysts." Chem. Eng. Prog. Symp. Ser. 63 (73) p. 86-9. CA 67-76578y.

\section{Beneficiation}

Whittemore, (O.J., Jr. (1971) "Mordenite Pellets". U. S. Patent $3,445,184$. CA $71-23334$ s.

Studer, H.P. (1968) "Separation of particles of different wettability." U.S. Patent 3,349,999. CA 6814574.

W.H. Grace and Co. (1967) "Shaped zeolites." Fr. Patent 1,466,594. CAA $67-55729 \mathrm{~h}$. 
Kiovsky, J.R. and W.J. Perreault, Jr. (1972) "Purification of zeolite ores." Ger. Offen. 2,052, 834 . CA $75-131225 \mathrm{~g}$.

\section{Dentifrice}

Kato, K.N. Nagata, Y. Sakai, M. Shiba and M. Onishi (1969) "Zeolite as polishing agent for dentifrice, I. (chemical) Properties of Zeolite." Iwate I)aigaku Nogakubu Hokoku, 3, 23-55. C.A 73-101946a.

\section{Ceramic Blocks}

Ookawa, Y. and Y. Motoki (1969) "Manufacturing lightweight ceramic blocks and bricks." Japan Pat. 69 23,817. CA 72-2553t.

\section{Pesticide Stabilizer}

Helfenberger, H. (1969) "Thiophosphate pesticides." Fr. Pat. 1,559,169. ('A 72-2553t.

\section{Filtration}

Shinohara, ()., C. Amitami (1971) "Filtration through unglazed porcelain filter made of zeolites." Kogyo Yosuii 149, p. 36-49. (:A 75-50737.

\section{Soil Conditioner}

Hsu, S.C., S.T. Want and T.H. Lin. (1967) "Effects of soil conditioners on Taiwan soils. I. Effects of zeorlites on physiochemical properties of soils." Nung Yeh Yen ('hiu. 16 (L) p), 50-57. (.A 66-104218.

\section{Analysis of Zeolites}

Haftka, F.G. (1967) "X-ray spectrographic analysis of transition elements in zeolites after wet decomposition." Fresenias 2. Anal. Chem. 23 (5) p. 3218. C:A 67-11:3489t.

Vainshtein, S.M., E.Y. Gienka, B.A. Lipkind, A.T. Slepneva (1967) "General method for evaluating the quality of synthetic zeolites." Tr. Vses. Nauch. Issted. Inst. Perarab. Nefti., 10, p. 32-50. (.A 69-8-0587j.

Yates, D.J.C. (1968) "Surface area of zeolites as determined by physical absorption and $x$-ray crystallography." (an. J. Chem. 46 (10), p. 1695-701. CA 69$22322 \mathrm{~h}$.

Northrup, M.A. (1941) "Home laboratory test for the identification of zeolites and related silicates." Rocks and Minerals 16, p. 275-9. CA 35-6899 7 .

\section{Precipitation in Radiators}

Lebedev, L.M., L.M. Gorakhova (1968) "Recent mineralization in technical structures of Pauzhetka. City (Kamchatka)." 1)okl. Akad. Nauk. SSSH. 182 (6), p. 1399-401. (.A 70-40551.

\section{Shear Strength}

Riecker, R.E. and T.P. Rooney (1968) "Shear strength and weakening of zeolitized tuff from Nevada Test Site." Am. Min. 52(7/8), p. 1174-8. CA 68-4961r. 